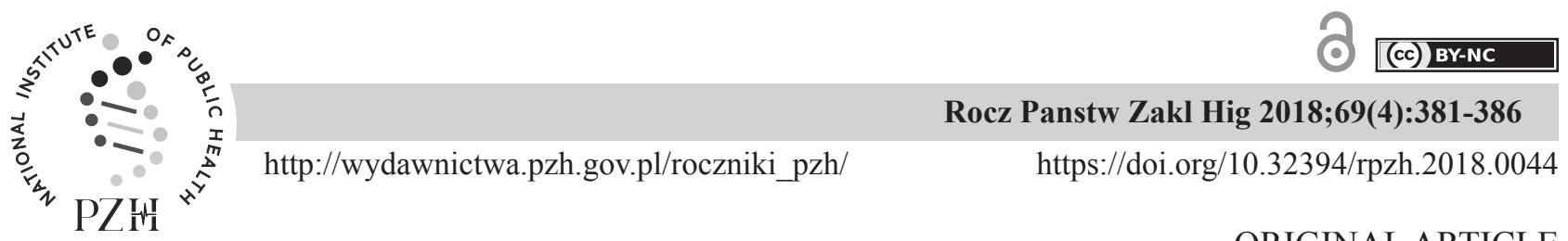

ORIGINAL ARTICLE

\title{
DIETARY INTAKE OF DHA DURING PREGNANCY: A SIGNIFICANT GAP BETWEEN THE ACTUAL INTAKE AND CURRENT NUTRITIONAL RECOMMENDATIONS
}

\author{
Regina Wierzejska ${ }^{1}$, Mirosław Jarosz ${ }^{1}$, Barbara Wojdal ${ }^{1}$ Magdalena Siuba-Strzelińska ${ }^{1}$ \\ ${ }^{1}$ Institute of Food and Nutrition, Clinic of Metabolic Diseases and Gastroenterology, \\ Department of Nutrition and Dietetics, Powsińska St. 61/63, 02-903 Warsaw, Poland
}

\begin{abstract}
Background: Docosahexaenoic acid (DHA) is indispensable to ensure proper development of the fetal central nervous system and pregnancy duration. Daily intake of DHA should be at least $100 \mathrm{mg}$ higher as compared to the pre-pregnancy values.

Objectives: The aim of the study was to evaluate DHA intake during pregnancy and compare it to the current recommendations.

Material and methods: A total of 100 pregnant women presenting for labor at the Department of Obstetrics, Gynecology and Oncology, Medical University of Warsaw, were included in the study. DHA intake from the following sources: fish and eggs, and DHA preparations collected based on the questionnaire was investigated.

Results: Low dietary DHA intake (median: $60 \mathrm{mg} / \mathrm{day}$ ) was observed. The values were only slightly higher (median: $90 \mathrm{mg}$ /day) after DHA preparations were taken into consideration because only $28 \%$ of the pregnant women used DHA preparations. Overall, $92 \%$ of the subjects consumed $<200 \mathrm{mg}$ of DHA a day, which was the result of insufficient fish consumption (mean: $15 \mathrm{~g} /$ day). Only $10 \%$ of the respondents ate fish twice a week, in which case the DHA dietary intake was statistically significantly higher (median: $160 \mathrm{mg} /$ day) $(\mathrm{p}=0.0232)$. Total median dietary DHA and EPA intake in the study population was $79 \mathrm{mg} /$ day.

Conclusions: The diet of pregnant women is largely deficient as far as DHA intake is concerned. Importantly, it is not possible to comply with current recommendations without dietary supplementation.
\end{abstract}

Key words: docosahexaenoic acid, DHA, eicosapentaenoic acid, EPA, intake, pregnant women, fish

\section{STRESZCZENIE}

Wprowadzenie: Kwas dokozaheksaenowy (DHA) jest niezbędny dla prawidłowego rozwoju centralnego układu nerwowego płodu, a także czasu trwania ciąży. Jego spożycie przez kobiety ciężarne powinno być co najmniej o 100 mg większe, niż przed zajściem w ciążę.

Cel: Celem badania było oszacowanie wielkości spożycia DHA przez kobiety ciężarne, w kontekście aktualnych zaleceń żywieniowych.

Material i metody: Badanie przeprowadzono wśród 100 kobiet ciężarnych, zgłaszających się do porodu w Klinice Położnictwa, Chorób Kobiecych i Ginekologii Onkologicznej Warszawskiego Uniwersytetu Medycznego. Spośród produktów spożywczych źródłami DHA były ryby i jaja, których częstość i wielkość spożycia ustalono w oparciu o ankietę. Ponadto uwzględniono przyjmowanie przez kobiety ciężarne preparatów zawierających DHA.

Wyniki: Stwierdzono małe spożycie DHA z dietą (mediana: $60 \mathrm{mg}$ dziennie). Po uwzględnieniu suplementacji diety spożycie to wzrosło nieznacznie (mediana: $90 \mathrm{mg}$ ), ponieważ tylko 28\% kobiet przyjmowało preparaty DHA. Ogółem $92 \%$ kobiet spożywało mniej, niż 200 mg DHA w ciągu dnia. Niewielkie spożycie DHA było konsekwencją zbyt małego spożycia ryb - średnio $15 \mathrm{~g} /$ dzień. Tylko $10 \%$ kobiet jadło ryby dwa razy w tygodniu i w przypadku takiego spożycia pobranie DHA z dietą było istotnie statystycznie większe (mediana: $160 \mathrm{mg}$ dziennie) (p=0.0232). Łączne spożycie DHA i EPA w całej grupie kobiet wynosiło - mediana $79 \mathrm{mg}$ dziennie.

Wnioski: Dieta kobiet ciężarnych jest w dużym stopniu niedoborowa w DHA. Bez suplementacji diety nie jest możliwa realizacja zaleceń, dotyczących spożycia tego składnika w okresie ciąży.

Słowa kluczowe: kwas dokozaheksaenowy (DHA), kwas eikozapentaenowy (EPA), spożycie, kobiety ciężarne, ryby

Corresponding author: Regina Wierzejska, Institute of Food and Nutrition, Powsińska St. 61/63, 02-903 Warsaw, Poland telephone: +4822 55097 47, Fax:+48 2284211 03, e-mail: rwierzejska@izz.waw.pl 


\section{INTRODUCTION}

Out of a multitude of nutritional components which are necessary during pregnancy, docosahexaenoic acid (DHA), a member of the omega-3 fatty acids family, plays a particularly important role [1,30]. Recently, DHA has attracted considerable amount of attention from various researchers. DHA performs several vital functions, from the moment of conception to old age. During the fetal life and the first few years of childhood, DHA constitutes an important structural component of the brain and the retina. Thus, its role in the development of the fetal central nervous system and the eye continues to be emphasized $[16,20,35]$. Importantly, the European Committee has allowed food producers to use the following health claim 'maternal DHA consumption contributes to normal brain and eye development in the fetus' [7].

DHA may also affect neonatal birth weight, duration of the pregnancy and the risk for postpartum depression $[1,23,38]$, but the current state of knowledge does not allow us to draw definite conclusions about the relationship between maternal DHA supplementation and neonatal size [6], or maternal depression [29]. On the other hand, the belief that DHA preparations lower the risk for preterm labor is becoming quite common $[1,11]$. Makrides et al., demonstrated that the dose of $800 \mathrm{mg} /$ day of DHA lowered the risk for preterm labor before 34 weeks of gestation [27], and an innovative randomized study by Giorlandino et al., revealed that vaginally administered $1000 \mathrm{mg}$ of DHA reduced the risk for preterm labor in high-risk patients [17].

A possible link between maternal DHA intake and the development of cognitive functions in children has been the subject of much debate among both, researchers and parents. Regardless, results of the randomized trials have not generated valid conclusions. The studies of Judge et al., and Campoy et al., have demonstrated beneficial effects of dietary supplementation. The former found that children born to mothers who consumed DHA-fortified foods in the second trimester of pregnancy were more successful in dealing with challenges at the age of 9 months [22], while the latter reported that higher DHA concentrations in the maternal blood was associated with better cognitive development in children aged 6.5 years [5]. Regardless, other authors did not observe a correlation between DHA supplementation during pregnancy and psychomotor development among infants aged 6 months [27], or 18 months [32]. Recent findings of a large, randomized ongoing trial from Australia, with the target group of 7-year-olds, have also been rather unoptimistic. So far, no beneficial links have been detected between maternal supplementation and the cognitive and motor functions in the children who were tested at the ages of 18 months and 4 years [19].

The amount of DHA transported across the placenta to the fetus is strictly correlated with maternal intake [3,
18], and DHA accumulation in the central nervous system occurs after 20 weeks of gestation [1, 4], so pre-term infants are at a particularly high risk for DHA deficiency $[16,21]$. Only a small amount of DHA is synthesized in the body from the alpha-linolenic acid, making DHA a necessary component of the diet [30]. Unfortunately, it can only be found in a few products. The highest amounts can be found in fatty fish $(100-2150 \mathrm{mg} / 100 \mathrm{~g})$, so the frequency of fish consumption determines dietary DHA intake. Lower DHA content can be found in eggs ( 80 $\mathrm{mg} / 100 \mathrm{~g}$ ) but, in case of frequent consumption, that source should not be underestimated [24].

The aim of the study was to evaluate DHA intake among pregnant women from the Warsaw region and to compare the results to the current recommendations on DHA intake. Moreover, due to the total volume of consumption of DHA and EPA expressed in nutrition standards, the consumption of these two components has been estimated as well as the consumption of omega-3 acids from the food products analyzed in the research (fish and eggs).

\section{MATERIAL AND METHODS}

The study included 100 pregnant women, who delivered at the Department of Obstetrics, Gynecology and Oncology, Medical University of Warsaw, in winter 2014/2015 and summer 2015. The exclusion criteria were the following: non-Polish nationality, multiple gestation, advanced stage of the delivery, chronic maternal diseases before pregnancy, and threatened course of labor. Informed written consent was obtained. Local Ethics Committee approved of the study (no. 10/162/KB/2014). Maternal characteristics are presented in Table 1 .

Table 1. Maternal characteristics

\begin{tabular}{|l|c|}
\hline Number of women & 100 \\
\hline Age (in years) mean \pm SD & $30.0 \pm 4.4$ \\
\hline $\begin{array}{l}\text { Education } \\
\text { higher, (\%) }\end{array}$ & 66 \\
other, (\%) & 34 \\
\hline $\begin{array}{l}\text { Place of residence } \\
\quad \text { Warsaw, (\%) }\end{array}$ \\
$\quad$ other, (\%) & 58 \\
\hline $\begin{array}{l}\text { Parity } \\
\text { primipara, (\%) }\end{array}$ & 42 \\
\hline multipara, (\%) & 42 \\
\hline Premature birth, (\%) & 58 \\
\hline Pre-pregnancy BMI (mean) \pm SD & 6 \\
\hline Gestational diabetes, (\%) & $22.7 \pm 3.8$ \\
\hline Pregnancy-induced hypertension, (\%) & 11 \\
\hline Smoking during pregnancy, (\%) & 9 \\
\hline Professionally active during pregnancy, (\%) & 15 \\
\hline Supplementation with vitamin / mineral & 58 \\
preparations, (\%) & 89 \\
\hline
\end{tabular}


In case of the research, the consumption of DHA, EPA, and omega-3 fatty acids coming from fish and eggs has been estimated using a questionnaire; the preparations including DHA have been taken into account in case of DHA. In order to precisely evaluate portion size, direct interviewing (face-to-face) and the 'Photo Album of Meals and Products' were used for data collection. All interviews were conducted by one dietician (the main author of the manuscript) in order to ensure data homogeneity. Mean DHA content values in fatty $(790 \mathrm{mg} / 100 \mathrm{~g})$ and lean fish $(210 \mathrm{mg} / 100 \mathrm{~g})$, as well as eggs ( $80 \mathrm{mg} / 100$ g, i.e. $40 \mathrm{mg}$ per egg) were taken from the Polish food composition database. Mean EPA and omega-3 fatty acids content in these products was calculated using the national data [24]. In light of significant differences between the content of various vitamin-mineral supplements for pregnant women, only those preparations - whose trade names included the following words 'omega 3', 'DHA', or 'fish liver oil' - were included in the analysis. Mean DHA content in such preparations (130 $\mathrm{mg}$ in a daily dose) was calculated based on information on the unit packages and the available literature $(20-600 \mathrm{mg})[10,34]$.

Table 2. DHA intake and its sources in the diet of pregnant women (100 subjects)

\begin{tabular}{|c|c|c|c|}
\hline \multirow{2}{*}{$\begin{array}{l}\text { Food } \\
\text { product }\end{array}$} & \multirow{2}{*}{$\begin{array}{l}\text { Number and } \\
\text { percentage } \\
\text { of women } \\
\text { n }(\%)\end{array}$} & \multicolumn{2}{|c|}{$\begin{array}{l}\text { Daily DHA intake } \\
\text { in the entire study } \\
\text { population (mg) }\end{array}$} \\
\hline & & median & $\begin{array}{c}\text { range } \\
(\min -\max )\end{array}$ \\
\hline fish & $79(79 \%)$ & 29 & $0-790$ \\
\hline eggs & $96(96 \%)$ & 16 & $0-80$ \\
\hline $\begin{array}{l}\text { supplementation } \\
\text { with DHA } \\
\text { preparations }\end{array}$ & $28(28 \%)$ & 21 & $0-300$ \\
\hline $\begin{array}{l}\text { total (from all } \\
\text { products) }\end{array}$ & 100 & 90 & $11-812$ \\
\hline
\end{tabular}

\section{Statistical analysis}

The normal distribution of all studied parameters was checked using Kolmogorov-Smirnov test. Normal variables were presented as the mean (minmax), not-parametric as the median (min-max). The Mann-Whitney test was used to compare the distribution of DHA intake between independent groups (education, age, place of residence, parity, smoking, gestational diabetes, an pregnancy-induced hypertension). The Chi square test was used to analyze the relationship between DHA supplementation and the abovementioned variables.

A logistic regression analysis was used to investigate a possible relationship between selected baseline characteristics (maternal age and education, place of residence, parity, smoking, season) and the frequency of fish consumption. The relation of statistically significant factors was expressed by the odds ratio (OR) and the $95 \%$ confidence interval ( $95 \%$ CI). The p-value of $<0.05$ was considered as statistically significant. Obtained data were analyzed using Statistica ver. 6.0 (Statsoft, Inc.).

\section{RESULTS}

\section{DHA consumption}

The median dietary DHA intake (fish and eggs) was $60 \mathrm{mg} /$ day in the entire study population. Fish constituted the main source of DHA (Table 2). Higher DHA intake (median $88 \mathrm{mg} /$ day) was found in those respondents who consumed fish, with varying frequency. DHA intake was statistically significantly higher (median $160 \mathrm{mg} /$ day) in women who were compliant with the recommendations regarding fish consumption (twice a week) $(\mathrm{p}=0.0232)$. However, only $8 \%$ of the pregnant women consumed $\geq 200 \mathrm{mg} /$ day of DHA with their food. Statistically significant differences $(p=0.0107)$ were found in the dietary DHA intake versus parity. Primiparas consumed less DHA (median $53 \mathrm{mg}$ ) as compared to multiparas ( $85 \mathrm{mg}$ ).

After including DHA preparations into the analysis, total DHA intake in the entire study population increased only slightly (median $90 \mathrm{mg} /$ day) due to the fact that only $28 \%$ of the women reported DHA supplementation. In that group, median total DHA intake was $201 \mathrm{mg} /$ day. No statistically significant relationship was found between DHA supplementation and maternal age, education, place of residence, parity, smoking during pregnancy, gestational diabetes and pregnancy-induced hypertension.

\section{Omega-3 fatty acids intake (including EPA)}

The median omega-3 intake from the analyzed groups of products (fish and eggs) was $93 \mathrm{mg} /$ day, out of that, $63 \%$ from fish. Out of all omega-3 fatty acids consumed with these products, median EPA intake was $20 \mathrm{mg} /$ day, and all of that from fish, as EPA is not found in eggs. Total median dietary DHA and EPA intake in the study population was $79 \mathrm{mg} /$ day, and fish was the source of $47 \mathrm{mg}$ of the total DHA and EPA intake. In the group of women who consumed fish twice a week, median dietary omega-3 intake was 314 $\mathrm{mg}$ /day, and DHA+EPA combined intake was $253 \mathrm{mg} /$ day, whereas DHA+EPA combined intake from fish alone was $227 \mathrm{mg} / \mathrm{day}$.

\section{DHA-sources intake (fish and eggs)}

A total of $79 \%$ of the respondents reported fish intake during pregnancy. Out of them, only $10 \%$ followed the recommendations, i.e. consumed fish twice a week, followed by: $32 \%$ - once a week, and $37 \%$ - even less often (1-3 times a month). The likelihood of frequent fish consumption (at least 
once a week) was 3-fold lower in case of primiparas as compared to multiparas $(\mathrm{OR}=0.32 ; 95 \% \mathrm{CI}: 0.13$, $0.78 ; \mathrm{p}=0.0145$ ). Mean fish consumption in the entire study population was $15 \mathrm{~g}$ /day (ranging from 3 to $100 \mathrm{~g}$ ). No statistically significant relationship was found between the frequency of fish consumption and other analyzed parameters (place of residence, age, education, smoking during pregnancy, season of the year). Most women who reported fish consumption opted for fatty fish (42\%), followed by lean fish (16\%), or both $(21 \%)$. Out of fatty fish, herring and salmon were the most popular, while pollock and cod were the most common choices among lean fish.

Mean egg intake was $0.5 \pm 0.4$ eggs/day, and $4 \%$ of the women reported total abstinence from eggs and egg-containing products.

\section{DISCUSSION}

DHA consumption in the group of pregnant women from our study was low and far below the recommended levels, even despite the lack of consensus in the scientific literature. According to the guidelines of the Institute of Food and Nutrition in Warsaw, pregnant women should consume an additional dose of 100-200 mg of DHA, apart from the standard recommended levels for adults $(250 \mathrm{mg} /$ day of DHA+EPA) [30]. The 2010 Expert Group position is that supplementation with $200 \mathrm{mg}$ /day of DHA (400-600 mg in case of low fish consumption) is necessary during pregnancy [9]. According to the 2015 recommendations of the Polish Gynecological Society, the recommended dose is $600 \mathrm{mg} /$ day of DHA, with $1000 \mathrm{mg}$ /day for women at high risk for preterm labor, as various authors have reported the effectiveness and safety of that dose [1, 11]. On average, consumption of 2 servings of fish a week (including at least one serving of fatty fish) supplies the body with $250 \mathrm{mg} /$ day of DHA and EPA [30]. However, in case of pregnant women, even absolute adherence to the guidelines will not ensure the recommended amount of DHA in their diet.

To the best of our knowledge, the literature offers only two reports on DHA intake among pregnant women in Poland. Harton et al., in their study on a relatively small group of pregnant women between 2011 and 2012, found that mean DHA intake was 87 $\mathrm{mg}$ /day, which is consistent with our findings [20]. Broś-Konopielko et al., in their study from 2017, reported a significantly higher DHA intake (mean: $280 \mathrm{mg}$ /day). However, these authors emphasized that over half of the subjects consumed $<200 \mathrm{mg}$ of DHA per day [3]. In our study, DHA intake of $<200 \mathrm{mg}$ /day in diet was found in $92 \%$ of the women. In the Western countries, DHA intake among pregnant women is also insufficient and has been reported at $<50 \%$ of the norm [23]. In the USA, Nordgren et al., found the mean daily
DHA intake to be $66 \mathrm{mg} /$ day [31], Loosemore et al., reported $68 \mathrm{mg} /$ day [25], and Gaitán et al., $72 \mathrm{mg} /$ day [15]. In New Zealand, DHA intake during pregnancy has been estimated at $110 \mathrm{mg} /$ day and almost $70 \%$ of the women consume $<200 \mathrm{mg} /$ day of DHA [12].

Low DHA intake is mainly the result of low fish consumption. In Poland, that fact has been known for years. In 2017, mean daily fish intake among the general population was $11 \mathrm{~g} /$ day [8]. According to the current nutritional recommendations, minimal fish consumption in a week should be 2 servings [30], which is approximately $30 \mathrm{~g} /$ day if $100 \mathrm{~g}$ of fish constitutes one serving. Bojar et al., reported such consumption (mean: $31 \mathrm{~g} /$ day) in their study on pregnant women [2], but in our study the levels were reduced by half (mean: $15 \mathrm{~g} /$ day), which is representative of the reported fish intake among women of the reproductive age (15 g/day) [37]. Low fish consumption $(9-12 \mathrm{~g} /$ day) among pregnant women has also been observed in Germany [16]. In our study, we excluded seafood other than fish due to the fact that it is not common in the diet of Polish pregnant women and is the source of only $0.5 \mathrm{mg} /$ day of DHA [3].

In our study, we found that $21 \%$ of the study population did not eat fish at all, which is similar to the findings of Broś-Konopielko et al. (23\%) [3]. Smaller percentage of women who do not eat fish has been published in the 'Health behaviors of pregnant women' report (13.4\%) [33], and the study by Eugowska et al. (5\%) [26]. Only $10 \%$ of our study population complied with the recommendations regarding fish consumption, which constitutes the mean from other studies in Poland, where such consumption was reported in $2.6 \%-19 \%$ of the women [3, 14, 26]. On a positive note, most respondents demonstrated a marked preference for fatty fish, which contain on average 4-fold more DHA as compared to lean fish. Thus, our findings have confirmed that 2 servings of fish per week are sufficient to ensure the recommended combined DHA and EPA consumption among the general adult population, but fail to meet the demands of a pregnant subject. In light of the media reports on chemical pollutants in fish, the goal to increase consumption of fish may be rather difficult to obtain. Importantly, the benefits of consuming 1-4 servings of fish per week during pregnancy outweigh the possible risks, according to the EFSA Scientific Committee [36]. Nevertheless, there is a distinct need to avoid consumption of large fish, especially those at high risk for mercury contamination (e.g. shark, swordfish, and marlin) $[13,28]$. Luckily, these kinds of fish have never been popular in Poland. Various authors reported herring, cod, and salmon to be the most commonly consumed fish among the studied populations $[3,26]$, which is consistent with our findings. 
In our study, we found that, despite numerous recommendations, DHA supplementation is very rare ( $28 \%$ of our subjects). Similar reports have been published about other countries, e.g. Germany (16\%), USA (9\%), and New Zealand (20\%) [12, 16,31]. The amount of DHA intake with such preparations is relatively modest (median: $21 \mathrm{mg} /$ day), but these calculations are merely rough estimates due to lack of reliable data of the preparations, frequent changes on the pharmaceutical market, and memory errors of the respondents as far as the exact kind of the product was concerned, which is a definite limitation of our study. Regardless, similar results (mean: $20 \mathrm{mg} /$ day) from dietary supplements have been reported by American authors [6]. A relatively small sample size and the fact that the study was conducted locally are additional limitations of our study. Thus, our findings need not necessarily reflect DHA intake in the population of Polish pregnant women.

\section{CONCLUSION}

In our study, we detected very low DHA intake among pregnant women from the Warsaw region. Also, we found that, due to insufficient consumption of fish, they failed to meet the recommended levels of DHA in the diet, not only for pregnant women but even for the general population. A small number of the respondents used DHA preparations, despite the guidelines on the need to supplement the diet of pregnant women.

\section{Acknowledgements}

The authors wish to express their sincere gratitude to the management and personnel of the Department of Obstetrics, Gynecology and Oncology, Medical University of Warsaw for their invaluable help and assistance in the project.

\section{Conflict of interest.}

The authors declare no conflict of interest.

\section{REFERENCES}

1. Bednarek W., Karowicz-Bilińska A., Kotarski J., Nowak-Markwitz E., Poręba R., Spaczyński M.: Rekomendacje Zespołu Ekspertów Polskiego Towarzystwa Ginekologicznego w zakresie stosowania kwasów omega-3 w położnictwie. Ginekol Pol 2010;81:467-469 (in Polish).

2. Bojar I., Owoc A., Humeniuk E., Fronczak A., Walecka I.: Quality of pregnant women's diet in Poland - macro-elements. Arch Med Sci 2014;10(2):361-365 doi: 10.5114/aoms.2013.35001.

3. Broś-Konopielko M., Białek A., Oleszczuk-Modzelewska L., Zaleśkiewicz B., Różańska-Walędziak A., TeligaCzajkowska J., Tokarz A., Czajkowski K.: Consumption of fish and seafood by pregnant Polish women and the supply of docosahexaenoic acid and eicosapentaenoic acid from these products. Family Medicine \& Prima- ry Care Review 2017;19(3):191-195 doi: https://doi. org/10.5114/fmpcr.2017.69272

4. Brouwer-Brolsma E.M., van de Rest O., Godschalk R., Zeegers M.P.A., Gielen M., de Groot R.H.M.: Associations between maternal long-chain polyunsaturated fatty acid concentrations and child cognition at 7 years of age: The MEFAB birth cohort. Prostaglandins Leukot Essent Fatty Acids 2017;126:92-97 doi: 10.1016/j. plefa.2017.09.012.

5. Campoy C., Escolano-Margarit M.V., Ramos R., Parrilla-Roure M., Csábi G., Beyer J., Ramirez-Tortosa M.C., Molloy A.M., Decsi T., Koletzko B.V.: Effects of prenatal fish-oil and 5-methyltetrahydrofolate supplementation on cognitive development of children at 6.5 y of age. Am J Clin Nutr 2011;94(6):1880S-1888S doi: 10.3945/ajen.110.001107.

6. Carlson S.E., Colombo J., Gajewski B.J., Gustafson K.M., Mundy D., Yeast J., Georgieff M.K., Markley L.A., Kerling E.H., Shaddy D.J.: DHA supplementation and pregnancy outcomes. Am J Clin Nutr 2013;97(4):808815 doi: 10.3945/ajen.112.050021.

7. Commission Regulation (EU) No 440/2011 of 6 May 2011 on the authorisation and refusal of authorisation of certain health claims made on foods and referring to children's development and health. Off J EU L 119/6, 7.5.2011

8. Concise statistical yearbook of Poland 2017, Central Statistical Office (in Polish). Available www.stat.gov.pl (Accessed 10.04.2018)

9. Czajkowski K., Czerwionka-Szaflarska M., Charzewska J., Chybicka A., Dobrzańska A., Gruszfeld D., Imiela J.R., Jackowska T., Helwich., Kaczmarski M., Poręba R., Książyk J.B., Lauterbach R., Lukas W., Mojska H., Milanowski A., Radowicki S., Ryżko J., Socha P., Szajewska H., Szczepa J., WalkowiakJ., Weker H.: Position paper of the expert group on DHA and other omega-3 fatty acid supplementation in pregnant and lactating women, infants and children up to 3 years of age. Standardy Medyczne/Pediatria 2010;7:729-736 (in Polish).

10. Dereń J.: Fish-liver oil and preparations with omega- 3 fatty acids. https://opieka.farm/opracowania/tran-i-preparaty-z-kwasami-omega-3/

11. Dębski R., Karowicz-Bilińska A., Oszukowski P., Paszkowski T., Spaczyński M.: Rekomendacje Polskiego Towarzystwa Ginekologicznego dotyczące zastosowania suplementacji kwasem dokozaheksaenowym w profilaktyce porodu przedwczesnego. Ginekol Pol 2014;85:318-320 (in Polish).

12. Eickstaedt M., Beck K.L., Conlon C.A.: New Zealand women have suboptimal intakes of long chain omega-3 polyunsaturated fatty acids during pregnancy - a cross sectional study. N Z Med J 2017;130(1462):37-45.

13. Environmental Protection Agency and Food and Drug Administration. Fish: what pregnant women and parents should know [cited 20.04.2017]. Available from URL: https://www.fda.gov/food/foodborneillnesscontaminants/metals/ucm393070.htm

14. Gacek M.: Some health behaviours and selected health status coefficients in a group of pregnant women. Probl Hig Epidemiol 2010;91(1):48-53 (in Polish). 
15. Gaitán A.V., Drewery M.L., Thaxton C.A., Carabante K.M., Seidemann E., Elkind-Hirsch K., Lammi-Keefe C.J.: Dietary intake and omega-3 DHA status in pregnant women who are overweight. J Obstet Gynecol Neonatal Nurs 2017;S0884-2175(17)30405-7 doi: 10.1016/j.jogn.2017.08.008.

16. Gellert S., Schuchardt J.P., Hahn A.: Higher omega-3 index and DHA status in pregnant women compared to lactating women - Results from a German nation-wide cross-sectional study. Prostaglandins Leukot Essent Fatty Acids 2016;109:22-28 doi: 10.1016/j.plefa.2016.04.002.

17. Giorlandino C., Giannarelli D.: Effect of vaginally administered DHA fatty acids on pregnancy outcome in high risk pregnancies for preterm delivery: a double blinded randomised controlled trial. J Prenat Med 2013;7(3):42-45.

18. Gould J.F., Treyvaud K., Yelland L.N., Anderson P.J., Smithers L.G., Gibson R.A., McPhee A.J., Makrides $M$ : Does n-3 LCPUFA supplementation during pregnancy increase the IQ of children at school age? Follow-up of a randomised controlled trial. BMJ Open 2016;6:e011465 doi: 10.1136/bmjopen-2016-011465.

19. Gould J.F., Treyvaud K., Yelland L.N., Anderson P.J., Smithers L.G., McPhee A.J., Makrides M.: Seven-year follow-up of children born to women in a randomized trial of prenatal DHA supplementation. JAMA 2017;317(11):1173-1175. doi: 10.1001/ jama.2016.21303.

20. Harton A., Choroszewska A., Gajewska D., Myszkowska-Ryciak $J$.: Intake of polyunsaturated fatty acids by pregnant women. Probl Hig Epidemiol 2013;94(3):605609 (in Polish).

21. Helland I. B., Smith L., Saarem K., Saugstad O.D., Drevon C.D.: Maternal supplementation with very long chain fatty acids during pregnancy and lactation augments children's IQ at 4 years of age. Pediatrics 2003;111:3944. http://dx.doi.org/10.1542/peds.111.1.e39

22. Judge M.P., Harel O., Lammi-Keefe C.J.: Maternal consumption of a DHA-functional food during pregnancy: comparison of infant performance on problem-solving and recognition memory tasks at 9 months of age. Am J Clin Nutr 2007;85:1572-1577.

23. Judge M.P., Casavant S.G., Dias J.A., McGrath J.M.: Reduced DHA transfer in diabetic pregnancies: mechanistic basis and long-term neurodevelopmental implications. Nutr Rev 2016;74(6):411-20; doi: 10.1093/nutrit/ nuw006.

24. Kunachowicz H., Przygoda B., Nadolna I., Iwanow K.: Food Composition Tables. Warsaw, PZWL, 2017 (in Polish).

25. Loosemore E.D., Judge M.P., Lammi-Keefe C.J.: Dietary intake of essential and long-chain polyunsaturated fatty acids in pregnancy. Lipids 2004;39(5):421-424.

26. Eugowska K., Kolanowski W.: Spożycie ryb przez kobiety w ciąży. [Fish consumption by pregnant women]. Żyw Człow Metabol 2017;2:87-97 (in Polish - abstract in English).
27. Makrides M., Gibson R.A., McPhee A.J., YellandL., Quinlivan J., Ryan P.; DOMInO Investigative Team.: Effect of DHA supplementation during pregnancy on maternal depression and neurodevelopment of young children: a randomized controlled trial. JAMA 2010;304(15):16751683. doi: 10.1001/jama.2010.1507.

28. Mania M., Wojciechowska-Mazurek M., Starska K., Rebeniak M., Postupolski J.: Ryby i owoce morza jako źródło narażenia na metylortęć. [Fish and seafood as a source of human exposure to methylmercury. Rocz Panstw Zakl Hig 2012;63(3):257-264 (in Polish - abstract in English).

29. Miller B.J., Murray L., Beckmann M.M., Kent T., Macfarlane B.: Dietary supplements for preventing postnatal depression. Cochrane Database Syst Rev 2013;(10):CD009104. doi: 10.1002/14651858. CD009104.pub2

30. Mojska H., Kłosiewicz-Latoszek L., Jasińska-Melon E., Gielecińska I.: Omega-3 fatty acids. (In) Norms of nutrition for Polish population (ed. Jarosz M.) IŻŻ, 2017:79-91 (in Polish).

31. Nordgren T.M., Lyden E., Anderson-Berry A., Hanson $C$.: Omega-3 fatty acid intake of pregnant women and women of childbearing age in the United States: Potential for deficiency? Nutrients 2017;9(3):197. doi:10.3390/nu9030197.

32. Ramakrishnan U., Stein A.D., Parra-Cabrera S., Wang M., Imhoff-Kunsch B., Juárez-Márquez S., Rivera $J$., Martorell R.: Effects of docosahexaenoic acid supplementation during pregnancy on gestational age and size at birth: randomized, double-blind, placebo-controlled trial in Mexico. Food Nutr Bull 2010;31(2):S108-1016.

33. Report "Health behaviors of pregnant women", Institute of Rural Health in Lublin, 2013 http://zdrowiewciazy.pl/pdf/publikacje/raport_zachowania_zdrowotne kobiet w ciazy.pdf

34. Sicińska P., Pytel E., Kurowska J., Koter-Michalak M.: Supplementation with omega fatty acids in various diseases. Postepy Hig Med Dosw (online), 2015;69:838852 (in Polish - abstract in English).

35. Socha P.: DHA supplementation in critical periods of life - how to implement Polish and International guidelines. Standardy Medyczne/Pediatria 2013;10:521-526 (in Polish).

36. Statement on the benefits of fish/seafood consumption compared to the risks of methylmercury in fish/seafood. EFSA Scientific Committee. www.efsa.europa.eu/efsajournal

37. Sygnowska E., Waśkiewicz A., GtuszekJ., Kwaśniewska M., Biela U., Kozakiewicz K., Zdrojewski T., Rywik $S$.: Spożycie produktów spożywczych przez dorosłą populację Polski. Wyniki programu WOBASZ. Kardiologia Polska 2005;63(6)(supl.4) (in Polish).

38. Wojcicki J.M., Heyman M.B.: Maternal omega-3 fatty acid supplementation and risk for perinatal maternal depression. J Matern Fetal Neonatal Med 2011;24(5):680-686.

Received: 10.07 .2018

Accepted: 08.10.2018

This article is available in Open Access model and licensed under a Creative Commons Attribution-Non Commercial 3.0.Poland License (CC-BY-NC) available at: http://creativecommons.org/licenses/by-nc/3.0/pl/deed.en 